\title{
Pengaruh Perputaran Kas dan Perputaran Persediaan Terhadap Profitabilitas
}

\author{
Sarjito Surya, Ruly Ruliana, Dedi Rossidi Soetama \\ Sekolah Tinggi Ilmu Ekonomi STAN Indonesia Mandiri \\ sarjito.surya@widyatama.ac.id
}

\begin{abstract}
A discussion about the influence of cash turnover and inventory turnover toward profitability still shows inconsistencies. Therefore, this study is conducted to know the relationship between the cash turnover and inventory turnover on profitability and also how big the relationship is. This study was conducted at automotive and allied products in periods of 2010 - 2013 with a total study population of 18 (eighteen) companies registered in the Indonesia Stock Exchange. The sampling technique used in this study is purposive sampling and acquired 8 (eight) samples of companies. The analysis technique used is multiple linear regressions, both partial ( $t$ test) and simultaneous test ( $F$ test). The dependent variable is profitability while the independent variable is cash turnover and inventory turnover. The results of this study show both simultaneous and partialtest on cash turnover and inventory turnover do not have a significant effect on profitability.
\end{abstract}

Key Words: profitability, cash turnover, inventory turnover.

\begin{abstract}
Abstrak
Pembahasan tentang pengaruh perputaran kas dan perputaran persediaan terhadap profitabilitas masih menunjukan ketidak konsistenan. Oleh karena itu penelitian ini dilakukan untuk mengetahui ada tidaknya hubungan antara perputaran kas dan perputaran persediaan terhadap profitabilitas. Penelitian ini dilakukan pada perusahaan otomotif dan komponennya periode tahun 2010 - 2013 dengan populasi penelitian sebanyak 18 (delapan belas) perusahaan yang terdaftar di Bursa Efek Indonesia. Teknik sampling yang digunakan dalam penelitian ini adalah purposive sampling lalu diperoleh sampel sebanyak 8 (delapan) perusahaan. Teknik analisis yang digunakan adalah analisis regresi linear berganda, uji simultan dan uji parsial. Variabel terikat yaitu profitabilitas, sedangkan variabel bebas yaitu perputaran kas dan perputaran persediaan. Hasil penelitian ini menunjukkan bahwa secara simultan maupun parsial perputaran kas dan perputaran persediaan tidak berpengaruh signifikan terhadap profitabilitas
\end{abstract}

Kata Kunci: profitabilitas, perputaran kas, perputaran persediaan

Diterima: 5 Mei 2017; Revisi: 25 Agustus 2017; Disetujui: 5 September 2017 


\section{PENDAHULUAN}

Kas merupakan pos paling penting karena secara langsung atau tidak langsung kas terlibat dalam hampir semua transaksi perusahaan bahkan sekiranya pun kas tidak terlibat secara langsung dalam suatu transaksi, namun pos ini memberi dasar bagi pengukuran dan akuntansi untuk semua pos yang lain (Smith, 1996). Perputaran kas adalah perbandingan antara penjualan dengan jumlah kas rata rata (Kasmir, 20ll). Perputaran kas merupakan kemampuan kas dalam menghasilkan pendapatan sehingga dapat dilihat berapa kali uang kas berputar dalam satu periode.

Persediaan merupakan salah satu pos dari aktiva lancar yang penting karena persediaan merupakan unsur yang aktif dalam operasi perusahaan yang terus menerus diperoleh, diubah, dan kemudian dijual kepada konsumen (Smith, 1996). Persediaan mempermudah atau memperlancar jalannya operasi perusahaan yang harus dilakukan secara berturut-turut untuk memproduksi barang barang serta mendistribusikannya kepada konsumen. Perputaran persediaan merupakan salah satu hal yang harus diperhatikan oleh perusahaan dalam operasi perusahaan itu sendiri. Persediaan harus dikelola dengan baik karena persediaan yang optimal dapat meningkatkan efektifitas perusahaan sehingga meningkatkan keuntungan yang diperoleh perusahaan. Untuk mempertahankan penjualan, perusahaan harus menjamin tersedianya persediaan (Ridwan, 2007)

Kelangsungan hidup perusahaan dipengaruhi oleh banyak hal antara lain profitabilitas perusahaan itu sendiri. Tujuan yang paling mendasar dari operasi perusahaan adalah memperoleh laba yang optimal. Profitabilitas suatu perusahaan menunjukan perbandingan antara laba dengan aktiva atau modal yang menghasilkan laba tersebut (Riyanto, 200I). Kekurangan kas menyebabkan perusahaan tidak mampu membayar kewajiban dalam jangka pendek sedangkan kekurangan persediaan akan menyebabkan perusahaan tidak dapat memperoleh keuntungan karena calon pembeli tidak jadi membeli ke perusahaan tersebut (Ridwan, 2007). Profitabilitas suatu perusahaan dapat diukur dengan rasio profitabilitas. Rasio profitabilitas didapat dengan membandingkan antara laba dengan aktiva atau modal yang menghasilkan laba. Ada beberapa ukuran yang dipakai untuk melihat kondisi profitabilitas perusahaan, antara lain: Gross Profit margin, Net Profit Margin, ROE, ROA, dan lain-lain. Dalam penelitian ini peneliti akan menggunakan ROA (Return On Assets). Rasio ini diukur dengan 
membandingkan antara laba bersih terhadap total aktiva. Kas dan persediaan merupakan unsur aktiva yang akan mempengaruhi pengembalian aktiva.

Beberapa penelitian yang telah dilakukan yang berkaitan dengan pengaruh perputaran kas dan perputaran persediaan terhadap profitabilitas yang hasilnya ada yang sejalan ataupun bertentangan. Penelitian-penelitian diantaranya yang dilakukan oleh $\mathrm{Ni}$ Kadek (2013) menunjukan secara parsial perputaran kas dan perputaran persediaan berpengaruh positif terhadap profitabilitas, Penelitian tersebut diperkuat oleh penelitian yang dilakukan oleh Albertus (20II) yang menunjukan perputaran kas berpengaruh positif terhadap profitabilitas. Akan tetapi ada beberapa penelitian yang mendapatkan hasil berbeda diantaranya penelitian yang dilakukan oleh Rosmawati (2013) yang menunjukan secara parsial perputaran kas dan perputaran persediaan tidak berpengaruh terhadap profitabilitas dan juga penelitian yang dilakukan oleh Ferlay (20I2) yang menunjukan secara parsial perputaran kas dan perputaran persediaan tidak berpengaruh terhadap profitabilitas sedangkan penelitian yang dilakukan oleh Nina (2010) menunjukan bahwa perputaran kas berpengaruh negatif terhadap profitabilitas dan perputaran persediaan berpengaruh positif terhadap profitabilitas dan juga penelitian yang dilakukan oleh Intan (201I) yang menunjukan perputaran kas tidak berpengaruh terhadap profitabilitas sedangkan perputaran persediaan berpengaruh positif terhadap profitabilitas. Dengan demikian terdapat inkonsistensi hasil penelitian sehingga peneliti ingin menguji kembali pengaruh perputaran kas dan perputaran persediaan terhadap profitabilitas dengan objek yaitu perusahaan otomotif dan komponennya yang terdaftar di Bursa Efek Indonesia (BEI).

\section{TINJAUAN KEPUSTAKAAN}

Tujuan manajemen kas diantaranya untuk menjaga likuiditas dan jumlah kas yang harus ada didalam perusahaan serta mengatur agar tiap pengeluaran perusahaan harus diarahkan untuk mendapatkan kemungkinan hasil yang lebih besar dibandingkan dengan kas yang dikeluarkan. Strategi yang dapat digunakan perusahaan untuk mengelola kas menurut Ridwan (2007:3II) adalah sebagai berikut: (I) Melaksanakan perputaran persediaan secepat mungkin tetapi menghindari kehabisan persediaan yang dapat mengakibatkan kerugian penjualan. (2) Menagih piutang secepat mungkin tanpa merugikan penjualan dimasa yang akan datang yang disebabkan oleh penagihan yang 
dipercepat. (3) Membayar hutang usaha selambat mungkin tanpa merusak rating kredit perusahaan tetapi tetap menerima keuntungan dari potongan tunai.

Menurut Kieso, et al (2007) kas adalah aktiva yang paling rentan disalahgunakan. Untuk melindungi kas dan menjamin keakuratan catatan akuntansi untuk kas, dibutuhkan pengendalian internal yang efektif atas kas. Manajemen biasanya menghadapi dua masalah akuntansi untuk transaksi kas: (I) Pengendalian yang tetap harus ditetapkan untuk menjamin bahwa tidak ada transaksi yang tidak diotorisasi dicatat oleh pejabat atau karyawan. (2) Menyediakan informasi yang diperlukan untuk mengelola kas yang ada ditangan dan transaksi kas dengan tepat.

Menurut Bambang Riyanto (200I) Perputaran kas (cash turnover) adalah perbandingan antara penjualan dengan jumlah kas rata-rata. Perputaran kas menunjukan efisiensi perusahaan karena tingkat perputaran kas menggambarkan kecepatan arus kas kembali menjadi kas yang telah diinvestasikan. Kas diperlukan perusahaan baik untuk membiayai operasi perusahaan sehari-hari maupun untuk mengadakan investasi baru dalam aktiva tetap.

Menurut Ridwan (2007) Persediaan yaitu barang atau bahan yang diperlukan dalam proses produksi dan distribusi yang digunakan untuk proses lebih lanjut atau dijual. Penilaian persediaan didasarkan pada PSAK no 14, yaitu: (I) Persediaan harus diukur berdasarkan biaya atau nilai realisasi, mana yang lebih rendah. (2) Biaya persediaan harus meliputi semua biaya pembelian, biaya konversi dan biaya lain yang timbul sampai persediaan berada dalam kondisi dan tempat yang siap untuk dijual atau dipakai. (3) Biaya persediaan untuk barang yang lazimnya tidak dapat diganti dengan barang lain dan barang serta jasa yang dihasilkan dan dipisahkan untuk proyek khusus harus diperhitungkan berdasarkan identifikasi khusus terhadap biayanya masing-masing. (4) Biaya persediaan, kecuali yang disebut dalam point (3) harus dihitung dengan menggunakan rumus biaya masuk pertama keluar pertama, rata rata tertimbang, atau masuk terakhir keluar pertama.

Selain pengertian persediaan yang dikemukan diatas, berikut ini pengertian persediaan menurut Kieso (2007) Persediaan adalah pos aktiva yang dimiliki oleh perusahaan untuk dijual dalam operasi bisnis normal, atau barang yang akan digunakan atau dikonsumsi dalam membuat barang yang akan dijual. Investasi dalam persediaan 
biasanya merupakan aktiva lancar paling besar dari perusahaan barang dagang dan manufaktur.

Persediaan merupakan unsur dari aktiva lancar yang merupakan unsur yang aktif dalam operasi perusahaan yang secara terus menerus diperoleh, diubah dan kemudian dijual kepada konsumen. Untuk mempercepat pengembalian kas melalui penjualan maka diperlukan suatu perputaran persediaan yang baik Perputaran persediaan menunjukan berapa kali persediaan diganti dalam waktu satu tahun. Dengan demikian, tingkat perputaran persediaan yang tinggi mengidentifikasikan bahwa tingkat penjualan yang tinggi pada perusahaan. Dengan tingkat perputaran persediaan yang tinggi berarti resiko kerugiaan dan biaya terhadap persediaan dapat diminimalkan. Menurut Warren et al (2005), perputaran persediaan (inventory turnover) adalah suatu alat untuk mengukur hubungan antara volume barang dagang yang dijual dengan jumlah persediaan yang dimiliki selama periode berjalan.

Menurut Sofyan (2010), profitabilitas menggambarkan kemampuan perusahaan mendapatkan laba melalui semua kemampuan dan sumber yang ada seperti kegiatan penjualan, kas, modal, jumlah karyawan, jumlah cabang, dan sebagainya. Menurut Riyanto (200I), profitabilitas suatu perusahaan menunjukan perbandingan antara laba dengan aktiva atau modal yang menghasilkan laba. Dalam suatu perusahaan masalah profitabilitas lebih penting daripada laba karena laba yang besar bukan ukuran perusahaan telah bekerja efisien. Profitabilitas adalah kemampuan perusahaan memperoleh laba dalam hubungannnya dengan penjualan, total aktiva maupun modal sendiri”. Para investor tetap tertarik terhadap profitabilitas perusahaan karena profitabilitas mungkin merupakan satu-satunya indikator yang paling baik mengenai kesehatan keuangan perusahaan (Sartono, 200I).

Dalam mengukur profitabilitas pada penelitian ini, peneliti menggunakan rasio Return on Assets (ROA) yang dapat dicapai dari tiap periode. Hal ini dikarenakan yang menjadi bahan penelitian yaitu kas dan persediaan termasuk ke dalam unsur aktiva. Rasio Return on Assets (ROA) merupakan indikator keberhasilan perusahaan atas pengelolaan kekayaan (aset) yang dimilik perusahaan, sehingga dengan meningkatnya Rasio return on assets (ROA) mencerminkan kinerja perusahaan baik dalam mengelola kekayaan yang dimilikinya, sehingga dapat menghasilkan keuntungan atau laba. 
Menurut Riyanto (200I) Perputaran kas adalah perbandingan antara penjualan dengan jumlah kas rata-rata”. Perputaran kas menunjukan efisiensi perusahaan karena tingkat perputaran kas menggambarkan kecepatan arus kas kembali menjadi kas yang telah diinvestasikan. Kas diperlukan perusahaan baik untuk membiayai operasi perusahaan sehari-hari maupun untuk mengadakan investasi baru oleh perusahaan kedalam berbagai bentuk aktivitas yang dapat menghasilkan laba sehingga dapat memaksimalkan profitabilitas perusahaan. Menurut Warren et al (2005) Perputaran persediaan (inventory turnover) adalah suatu alat untuk mengukur hubungan antara volume barang dagang yang dijual dengan jumlah persediaan yang dimiliki selama periode berjalan. Perputaran persediaan menunjukan berapa kali persediaan diganti dalam waktu satu tahun. Dengan demikian, Perputaran persediaan yang tinggi akan meningkatkan penjualan yang akan menghasilkan laba sehingga dapat menghasilkan profitabilitas perusahaan.

Beberapa hasil penelitian mengenai pengaruh perputaran kas dan perputaran persediaan terhadap profitabilitas diantaranya:

I. Penelitian Ni Kadek (20 I 2)

Penelitian yang dilakukan oleh Ni Kadek dan I putu Yahya yang berjudul Pengaruh Perputaran Kas, Perputaran Piutang dan Perputaran Persediaan terhadap Profitabilitas pada perusahaan food and beverages dengan sampel penelitian 13 perusahaan dengan periode tahun 2010 - 2012 dengan hasil penelitian diketahui perputaran kas, perputaran piutang dan perputaran persediaan berpengaruh positif terhadap profitabilitas.

2. Penelitian Albertus (20II)

Penilitian yang dilakukan oleh Albertus yang berjudul Pengaruh perputaran Kas dan Perputaran Piutang Terhadap Profitabilitas pada KPRI di lingkukgan BKN dengan hasil penelitian menunjukan perputaran kas dan perputaran piutang berpengaruh positif terhadap profitabilitas. Metode yang digunakan analisis regresi berganda, $U_{j i} f$ dan Uji t.

\section{Penelitian Rosmawati}

Penelitian yang dilakukan oleh Rosmawati yang berjudul Pengaruh Perputaran modal kerja Terhadap Profitabilitas pada perusahaan manufaktur yang terdaftar di BEI menunjukan secara parsial perputaran piutang berpengaruh positif terhadap 
profitabilitas tetapi perputaran kas dan perputaran persediaan tidak berpengaruh terhadap profitabilitas. Metode yang digunakan uji regresi berganda, uji F, Uji t.

4. Penelitian Ferlay

Penelitian yang dilakukan oleh Ferlay yang berjudul Pengaruh perputaran kas, perputaran Piutang, Perputaran Persediaan, dan Perputaran Hutang Terhadap Profitabilitas pada perusahaan Manufaktur yang menggunakan 18 sampel perusahaan dengan hasil penelitian hanya perputaran piutang yang berpengaruh terhadap profitabilitas

5. Penelitian Nina

Penelitian Nina Sufiana dan Ni Ketut Purnawati yang berjudul Perputaran Kas, Perputaran Piutang dan Perputaran Persediaan terhadap Profitabilitas, dari hasil penelitian yang dilakukan diketahui bahwa perputaran kas, perputaran piutang, perputaran persediaan secara simultan berpengaruh positif terhadap profitabilitas. Sedangkan analisis secara parsial menunjukan hanya perputaran piutang dan perputaran persediaan yang berpengaruh terhadap profitabilitas. Metode analisis yang digunakan menggunakan regresi linier berganda, uji F dan uji T.

6. Penelitian Putu Intan dan Gede Merta

Penelitian Putu Intan dan Gede Merta yang berjudul Pengaruh Modal kerja terhadap Profitabilitas dengan hasil penelitian perputaran kas berpengaruh negatif terhadap profitabilitas sedangkan perputaran piutang dan perputaran persediaan yang berpengaruh terhadap profitabilitas. Periode waktu yang diteliti yaitu 3 tahun antara tahun 2008 - 2010 dengan metode penelitian Regresi linier berganda, uji t, uji f.

Berdasarkan latar belakang, landasan teori, tinjauan teoritis dan hasil penelitian terdahulu yang memberikan kesimpulan bahwa ada pengaruh perputaran kas dan perputaran persediaan terhadap profitabilitas, maka dapat dibuat model atas penelitian ini seperti yang digambarkan sebagai berikut:

Dalam penelitian hipotesis yang akan diuji adalah hipotesis yang berkaitan dengan pengaruh perputaran kas dan perputaran persediaan terhadap profitabilitas (studi pada perusahaan otomotif dan komponen yang terdaftar di Bursa Efek Indonesia Periode Tahun 2010 - 2013). Maka hipotesis penelitiannya adalah sebagai berikut:

$\mathrm{HI}$ : Perputaran kas berpengaruh positif signifikan terhadap profitabilitas

H2 : Perputaran persediaan berpengaruh positif signifikan terhadap profitabilitas . 
H3 : Perputaran kas dan perputaran persediaan berpengaruh positif terhadap profitabilitas.

\section{METODE}

Metode yang digunakan dalam penelitian ini adalah deskriptif dan metode verifikatif. Metode deskriptif adalah metode yang digunakan untuk mendeskripsikan atau memberi gambaran terhadap objek penelitian melalui data sampel atau populasi sebagaimana adanya, tanpa bermaksud membuat kesimpulan yang berlaku umum atau generaliasasi (Sugiyono, 2013). Sedangkan metode verifikatif digunakan untuk melakukan uji hipotesis melalui pengolahan dan pengujian secara sistematis yaitu menguji pengaruh perputaran kas dan perputaran persediaan terhadap profitabilitas.

Terdapat beberapa unit analisis, yaitu individual, pasangan, kelompok, organisasi, dan kebudayaan. Dalam penelitian ini, unit analisis yang digunakan adalah laporan keuangan organisasi, yaitu laporan keuangan perusahaan otomotif dan komponennya yang terdaftar di Bursa Efek Indonesia (BEI) periode 2010 - 2013.

Populasi adalah wilayah generalisasi yang terdiri atas: Obyek/subyek yang mempunyai kualitas dan karakteristik tertentu yang ditetapkan penelitian untuk dipelajari dan kemudian ditarik kesimpulan (Sugiyono, 2013). Populasi dalam penelitian ini adalah perusahaan-perusahaan otomotif dan komponennya yang terdaftar di Bursa Efek Indonesia (BEI) periode 2010-2013 yang berjumlah I8 perusahaan.

\section{Tabel I. Sampel Penelitian}

\begin{tabular}{cl}
\hline No & \multicolumn{1}{c}{ Nama Perusahaan } \\
\hline I. & PT. Astra International, Tbk \\
2. & PT. Gajah Tunggal, Tbk \\
3. & PT. Indomobil Sukses International, Tbk \\
4. & PT. Multi Prima Sejahtera, Tbk \\
5. & PT. Prima Alloy Steel Universal, Tbk \\
6. & PT. Selamat Sempurna, Tbk \\
7. & PT. Tunas Ridean, Tbk \\
8. & PT. United Tractor, Tbk \\
\hline
\end{tabular}

Sumber: Data yang telah diteliti

Teknik pengambilan sampel yang digunakan adalah purposive sampling, yaitu teknik penentuan sample dengan pertimbangan tertentu (Sugiyono, 20I3). Sample yang digunakan dalam penelitian ini dipilih berdasarkan kriteria sebagai berikut: (I) 
Perusahaan yang terdaftar di Bursa Efek Indonesia (BEI) pada kurun waktu penelitian 2010-2013 dan tidak di delisting selama kurun waktu penelitian tersebut. (2) Perusahaan Otomotif dan Komponennya yang terdaftar di BEI yang menerbitkan laporan keuangan secara berturut-turut pada periode 2010-20I3. (3) Perusahaan yang mengalami keuntungan (profit) selama periode pengamatan. (4) Perusahaan yang menerbitkan laporan keuangan dengan mata uang rupiah

Sesuai dengan data yang diperlukan yaitu data sekunder, maka metode pengumpulan data dalam penelitian ini adalah menggunakan teknik dokumentasi yang berdasarkan laporan keuangan periode 2010-2013 yang dipublikasikan oleh Bursa Efek Indonesia (BEI) melalui ICMD dan juga dengan mengunduh laporan keuangan melalui situs www.idx.co.id. Adapun pengolahan dalam penelitian dengan menggunakan SPSS 20.0 .

Variabel penelitian adalah suatu atribut dan sifat atau nilai orang, objek atau kegiatan yang mempunyai variasi tertentu yang ditetapkan oleh peneliti untuk mempelajari dan kemudian ditarik kesimpulannya.

\section{Teknik Analisis Data}

Statistik deskriptif adalah statistik yang berfungsi untuk mendeskripsikan atau member gambaran terhadap objek yang diteliti melalui data sampel atau populasi sebagaimana adanya, tanpa melakukan analisis dan membuat kesimpulan yang berlaku umum (Sugiyono, 2013). Alat analisis yang digunakan dalam penelitian ini adalah maksimal, minimal, rata-rata (mean) dan standar deviasi untuk mendeskripsikan variabel perputaran kas, perputaran persediaan dan profitabilitas (ROA) pada perusahaan otomotif dan komponennya yang terdaftar di Bursa Efek Indonesia (BEI) selama 20II2013.

\section{Skor Rata-rata}

Rata-rata (mean) merupakan teknik penjelasan kelompok yang didasarkan atas nilainilai dari kelompok tersebut (Sugiyono, 2013). Rata-rata didapat dengan menjumlahkan seluruh data perusahaan dalam kelompok tertentu.

2. Standar Deviasi

Standar deviasi atau simpangan baku merupakan salah satu teknik statistic yang digunakan untuk menjelaskan homogenitas kelompok. Standar deviasi merupakan 
akar varians atau akar jumlah kuadrat semua deviasi nilai-nilai individual terhadap rata-rata kelompok (Sugiyono, 2013).

\section{Analisis Korelasi}

Analisis kolerasi bertujuan untuk mengukur ada atau tidaknya hubungan serta arah hubungan dua variabel atau lebih. Dalam analisis korelasi terdapat koefisien korelasi. Koefisien korelasi yaitu angka yang menyatakan derajat hubungan antara variabel independen dengan variabel dependen atau untuk mengetahui kuat atau lemahnya hubungan antara variabel independen dengan variabel dependen. Variabel yang akan diuji korelasinya adalah perputaran kas, perputaran persediaan dan profitabilitas (ROA). Adapun kriteria penilaian korelasi menurut Sugiono (2013:) yaitu:

Tabel 2. Kriteria Korelasi

\begin{tabular}{cc}
\hline Interval koefisien & Tingkat Hubungan \\
\hline $0,00-0,199$ & Sangat Rendah \\
$0,20-0,399$ & Rendah \\
$0,40-0,599$ & Sedang \\
$0,60-0,799$ & Kuat \\
$0,80-1,00$ & Sangat kuat \\
\hline
\end{tabular}

\section{Regresi Linear Berganda}

Analisis regresi berganda digunakan untuk meramalkan bagaimana keadaan (naik turunnya) variabel dependen, bila dua atau lebih variabel independen sebagai indicator. Analisis ini digunakan dengan melibatkan variabel dependen ( $Y$ ) dan variabel independen (XI dan X2

\section{Koefisien Determinasi}

Koefisien determinasi (R2) merupakan ukuran untuk mengetahui kesesuaian atau ketetapan hubungan antar variabel independen dengan variabel dependen dalam suatu persamaan regresi. Tingkat pengaruh atau tinggi rendahnya pengaruh perputaran kas dan perputaran persediaan terhadap profitabilitas dapat diukur denganmenggunakan persamaan koefisien determinasi.

\section{HASIL DAN PEMBAHASAN}

Setelah menjabarkan mengenai hal-hal yang melatarbelakangi penelitian ini, teori yang mengukuhkan teori yang diteliti, maupun metode penelitian yang digunakan, pada bab ini akan memaparkan mengenai hasil penelitian. Penelitian ini dilakukan pada 
Perusahaan Otomotif dan Komponennya yang terdaftar di Bursa Efek Indonesia periode tahun 2010 - 2013. Berdasarkan kriteria yang ditetapkan maka diperoleh sebanyak 8 perusahaan sehingga jumlah data yang digunakan pada penelitian ini sebanyak 32 data.

Tabel 3. Perputaran Kas Perusahaan Otomotif dan Komponennya

\begin{tabular}{|c|c|c|c|c|c|c|}
\hline \multicolumn{7}{|c|}{ Perputaran Kas } \\
\hline \multirow{2}{*}{ Kode } & \multicolumn{4}{|c|}{ Tahun } & \multirow{2}{*}{$\begin{array}{l}\text { Rata - rata } \\
\text { Perusahaan }\end{array}$} & \multirow{2}{*}{ Kriteria } \\
\hline & 2010 & 2011 & 2012 & 2013 & & \\
\hline ASII & 16,52 & 16,16 & 15,56 & 13,09 & 15,34 & Cukup \\
\hline GJTL & 11,72 & 16,3 & 16,87 & 8,51 & 13,35 & Cukup \\
\hline IMAS & 23,67 & 15,14 & 14,42 & $|7,8|$ & 17,76 & Cukup \\
\hline LPIN & 2,11 & 1,68 & $|, 6|$ & $\mathrm{I}, 53$ & $\mathrm{I}, 73$ & Rendah \\
\hline PRAS & 26,3 & 19,97 & 39,48 & 31,68 & 29,36 & Tinggi \\
\hline SMSM & 13,37 & 11,09 & 5,29 & 3,03 & 8,2 & Rendah \\
\hline TURI & 27,57 & 27,09 & 28,97 & 46,74 & 32,59 & Tinggi \\
\hline UNTR & 18,15 & 12,99 & 10,05 & 8,55 & 12,44 & Rendah \\
\hline $\begin{array}{l}\text { Rata - rata per } \\
\text { tahun }\end{array}$ & 17,43 & 15,05 & 16,53 & 16,37 & 16,35 & Cukup \\
\hline Max & 27,57 & 27,09 & 39,48 & 46,74 & 35,22 & Tinggi \\
\hline Min & 2,11 & 1,68 & $1,6 \mid$ & $\mathrm{I}, 53$ & $\mathrm{I}, 73$ & Rendah \\
\hline
\end{tabular}

Sumber: data yang telah diteliti

Perputaran kas menggambarkan kecepatan arus kas kembali menjadi kas yang telah diinvestasikan. Tingkat perputaran kas menunjukan kecepatan perubahan kembali aktiva lancar menjadi kas. Rata-rata perputaran kas pada perusahaan otomotif dan komponennya pada tahun 2010 menunjukkan tingkat perputaran kas yaitu 17,43 yang artinya perputaran kas selama satu periode mengalami 17 kali. Kemudian pada tahun 20 I I perputaran kas mengalami penurunan menjadi I5 kali putaran yang menunjukkan bahwa perusahaan kurang baik dalam menginvestasikan kasnya. Pada tahun 2012 rata rata perputaran kas mengalami peningkatan menjadi 17 kali putaran. Pada tahun 2013 perusahaan menunjukkan rata rata perputaran kasnya yaitu sebesar 16 kali putaran. Tingkat perputaran kas tertinggi dimiliki oleh PT Tunas Ridean Tbk yang memiliki nilai rata - rata sebesar 32,59 atau 33 kali perputaran kas hal ini terjadi karena jumlah kas relatif kecil dan penjualan dari tahun ke tahun mengalami kenaikan sedangkan tingkat perputaran terendah dimiliki oleh PT. Multi Prima Sejahtera, Tbk yang rata - rata perputaran kasnya sebesar I,73 atau 2 kali perputaran kas. Hal ini terjadi karena adanya 
jumlah kas dalam jumlah yang besar sehingga mencerminkan banyaknya dana yang menganggur atau kurang efektifnya dalam pengelolan kas .Perputaran kas yang terjadi di perusahaan Otomotif dan Komponennya periode tahun 2010 - 2013 dengan rata rata perputaran kas mengalami 16,35 kali atau 16 kali perputaran kas termasuk dalam kriteria cukup baik.

Perputaran Persediaan digunakan untuk hubungan antara volume penjualan dengan jumlah persediaan yang dimiliki selama periode berjalan. Tingkat perputaran persediaan yang tinggi mengidentifikasikan bahwa tingkat penjualan yang tinggi. Jumlah perputaran persediaan perusahaan otomotif dan komponennya menunjukkan penurunan dari awal hingga akhir periode. Pada tahun 2010 yang merupakan awal periode menunjukkan tingkat rata - rata perputaran persediaan tertinggi yaitu 7,06 atau 7 kali putaran. Kemudian pada tahun 201 I perputaran persediaan mengalami penurunan menjadi 6,84. Pada tahun 2012 perputaran persediaan kembali mengalami penurunan menjadi 6,10. Kemudian pada tahun 2013 perputaran persediaan juga mengalami penurunan menjadi 5,69. Hal ini dapat disimpulkan bahwa perusahaan otomotif dan komponennya mengalami penurunan perputaran persediaan yang mengakibatkan menurunnya penjualan.

Tabel 4. Perputaran Persediaan Perusahaan Otomotif dan Komponennya

\begin{tabular}{|c|c|c|c|c|c|c|}
\hline \multicolumn{7}{|c|}{ Perputaran Persediaan } \\
\hline \multirow{2}{*}{ Kode } & \multicolumn{4}{|c|}{ Tahun } & \multirow{2}{*}{$\begin{array}{l}\text { Rata - rata } \\
\text { Perusahaan }\end{array}$} & \multirow{2}{*}{ Kriteria } \\
\hline & 2010 & 2011 & 2012 & 2013 & & \\
\hline ASII & 11,38 & $\mathrm{II}, 43$ & 11,13 & 10,67 & $\mathrm{II}, \mathrm{I5}$ & Tinggi \\
\hline GJTL & 8,11 & 7,4 & 6,46 & 6,11 & 7,02 & Cukup \\
\hline IMAS & 8,35 & 7,03 & 5,51 & 4,2 & 6,27 & Cukup \\
\hline LPIN & 1,33 & 1,35 & $|, 6|$ & 1,37 & $\mathrm{I}, 4 \mathrm{I}$ & Rendah \\
\hline PRAS & 2,48 & 2,77 & 2,3 & 1,89 & 2,36 & Rendah \\
\hline SMSM & 3,33 & 4,09 & 3,92 & 4,22 & 3,88 & Rendah \\
\hline TURI & $|5,9|$ & 14,3 & 11,52 & 10,82 & 13,14 & Tinggi \\
\hline UNTR & 5,6 & 6,38 & 6,35 & 6,22 & 6,14 & Cukup \\
\hline $\begin{array}{l}\text { Rata - rata per } \\
\text { tahun }\end{array}$ & 7,06 & 6,84 & 6,1 & 5,69 & 6,42 & Cukup \\
\hline Max & $|5,9|$ & 14,3 & 11,52 & 10,82 & 13,14 & Tinggi \\
\hline Min & I,33 & $\mathrm{I}, 35$ & $\mathrm{I}, 6 \mathrm{I}$ & I,37 & 1,42 & Rendah \\
\hline
\end{tabular}

Sumber: data yang telah diteliti 
Tingkat perputaran persediaan tertinggi dimiliki oleh PT Tunas Raiden Tbk yang rata - rata perputaran persediaannya sebesar 13,14 atau I3 kali perputaran persediaan. Hal ini dapat dilihat dari penjualan yang tiap tahun mengalami peningkatan sehingga dalam penggunaan persediaannya cepat sedangkan tingkat perputaran terendah dimiliki oleh perusahaan PT. Multi Prima Sejahtera Tbk yang rata - rata perputaran persediaannya sebesar I,4I atau I kali perputaran persediaan. Hal ini terjadi karena penjualan yang terjadi relatif rendah sedangkan nilai persediaannya besar. Perputaran persediaan yang terjadi di perusahaan Otomotif dan Komponennya periode tahun 2010 - 2013 rata rata mengalami 6,42 atau 6 kali perputaran persediaan dan termasuk ke dalam kriteria cukup baik.

Return On Asset (ROA) merupakan rasio untuk menghitung perbandingan antara laba bersih dengan total aktiva perusahaan. Rasio ini menggambarkan kemampuan perusahaan untuk menghasilkan laba dari setiap aktiva yang tersedia.

Tabel 5. Profitabilitas (ROA) Perusahaan Otomotif dan Komponennya

\begin{tabular}{|c|c|c|c|c|c|c|}
\hline \multicolumn{7}{|c|}{ Profitabilitas } \\
\hline \multirow{2}{*}{ Kode } & \multicolumn{4}{|c|}{ Tahun } & \multirow{2}{*}{$\begin{array}{l}\text { Rata - rata } \\
\text { Perusahaan }\end{array}$} & \multirow{2}{*}{ Kriteria } \\
\hline & 2010 & 2011 & 2012 & 2013 & & \\
\hline ASII & 15,22 & 13,83 & 12,32 & 11,08 & $|3,1|$ & Tinggi \\
\hline GJTL & 7,94 & 7,81 & 8,44 & 2,22 & 6,6 & Rendah \\
\hline IMAS & 6,62 & 8,39 & 5,03 & 3,61 & 5,91 & Rendah \\
\hline LPIN & 9,36 & 7,19 & 9,64 & 4,36 & 7,64 & Cukup \\
\hline PRAS & 12,28 & 1,47 & 7,18 & 10,95 & 7,97 & Cukup \\
\hline SMSM & 13,53 & $|6,7|$ & 16,36 & 19,88 & 16,62 & Tinggi \\
\hline TURI & $|2,8|$ & 12,62 & $\mathrm{I} \mid, 77$ & 9,49 & 11,67 & Cukup \\
\hline UNTR & 13,04 & $|2,7|$ & 11,49 & 8,43 & 11,42 & Cukup \\
\hline Rata - rata per & & & & & & Cukup \\
\hline tahun & 11,35 & 10,09 & 10,28 & 8,75 & 10,12 & \\
\hline Max & 15,22 & $|6,7|$ & 16,36 & 19,88 & 17,04 & Tinggi \\
\hline Min & 6,62 & I,47 & 5,03 & 2,22 & 3,86 & Rendah \\
\hline
\end{tabular}

Sumber: data yang telah diteliti

Jumlah rata - rata Profitabilitas (ROA) pada perusahaan tahun 2010 menunjukkan tingkat profitabilitas (ROA) sebesar II,35 dan menjadi tingkat profitabilitas yang tertinggi pada periode tahun 2010 - 20I3. Pada tahun 20II tingkat profitabilitas (ROA) mengalami penurunan menjadi 10,09. Pada tahun 2012 tingkat profitabilitas (ROA) mengalami peningkatan menjadi 10,28. Sedangkan pada tahun 2013 
tingkat profitabilitas (ROA) perusahaan mengalami penurunan menjadi 8,75. Tingkat profitabilitas (ROA) tertinggi dimiliki oleh PT Selamat Sempurna Tbk yang memiliki rata - rata tingkat profitabilitas (ROA) sebesar 16,62 sedangkan tingkat profitabilitas yang paling rendah yaitu PT. Indomobil Sukses International, Tbk dengan nilai rata - rata profitabilitas 5,9I. Rata - rata profitabilitas yang terjadi pada perusahaan Otomotif dan Komponennya sebesar 10,12 \% dan termasuk ke dalam kriteria cukup baik.

Analisis koefisien korelasi digunakan untuk mengetahui besarnya pengaruh atau hubungan antara dua variabel bebas $(\mathrm{X})$ dengan variabel terikat $(\mathrm{Y})$. Ukuran yang dipakai untuk menentukan derajat hubungan korelasi dinamakan koefisien korelasi. Dalam penelitian ini korelasi yang digunakan adalah korelasi sederhana (Bivariate Correlation).

Hasil perhitungan korelasi sederhana (Bivariate Correlation) dengan menggunakan SPSS versi 20.0, maka hasil lengkap disajikan dalam tabel di bawah ini:

Tabel 6. Koefisien Korelasi

\begin{tabular}{|c|c|c|c|c|}
\hline & & $\bar{Y}$ & XI & $\mathrm{X} 2$ \\
\hline & $Y$ & 1.000 & $-.04 \mid$ & .252 \\
\hline Pearson Correlation & $\begin{array}{l}\times 1 \\
\times 2\end{array}$ & $\begin{array}{r}-.041 \\
.252\end{array}$ & $\begin{array}{c}1.000 \\
.395\end{array}$ & $\begin{array}{l}.395 \\
1.000\end{array}$ \\
\hline Sig. (I-tailed) & $\begin{array}{c}\mathrm{Y} \\
\mathrm{X} 1 \\
\mathrm{X} 2\end{array}$ & $\begin{array}{c}. \\
.411 \\
.082\end{array}$ & $\begin{array}{c}.411 \\
.013\end{array}$ & $\begin{array}{c}.082 \\
.013 \\
.\end{array}$ \\
\hline $\mathrm{N}$ & $\begin{array}{c}Y \\
X 1 \\
X 2\end{array}$ & $\begin{array}{l}32 \\
32 \\
32\end{array}$ & $\begin{array}{l}32 \\
32 \\
32\end{array}$ & $\begin{array}{l}32 \\
32 \\
32\end{array}$ \\
\hline
\end{tabular}

Besarnya koefisien antar variabel independen dengan Profitabilitas adalah sebagai berikut: (I) Nilai koefisien antara variabel perputaran kas dengan profitabilitas (ROA) adalah - 0,04I yang berarti hubungan antara perputaran kas terhadap profitabilitas adalah sangat rendah dan negatif. Sedangkan tingkat signifikasi sebesar 0,4II menunjukan 0,4II>0,05 sehingga dapat disimpulkan korelasi antara perputaran kas dengan profitabilitas (ROA) adalah tidak signifikan. (2) Nilai koefisien antara variabel perputaran persediaan dengan profitabilitas (ROA) adalah 0,252 yang berarti hubungan antara perputaran persediaan terhadap profitabilitas adalah rendah. Sedangkan tingkat 
signifikasi sebesar 0,082 menunjukan 0,082> 0,05 sehingga dapat disimpulkan korelasi antara perputaran persediaan dengan profitabilitas (ROA) adalah tidak signifikan.

Tabel 7. Persamaan Regresi Linear Berganda

\begin{tabular}{llrrrrr}
\hline Model & \multicolumn{2}{c}{$\begin{array}{c}\text { Unstandardized } \\
\text { Coefficients }\end{array}$} & $\begin{array}{c}\text { Standardized } \\
\text { Coefficients }\end{array}$ & $\mathrm{t}$ & Sig. \\
& $\mathrm{B}$ & Std. Error & \multicolumn{1}{c}{ Beta } & & \\
\hline (Constant) & 9.010 & $\mathrm{I} .59 \mathrm{I}$ & & $5.66 \mathrm{I}$ & .000 \\
$\mathrm{I} \quad$ & $\begin{array}{l}\text { Perputaran Kas } \\
\text { Perputaran }\end{array}$ & -.065 & .076 & -.167 & -.866 & .394 \\
& Persediaan & .339 & .206 & .318 & 1.648 & .110 \\
\hline
\end{tabular}

a. Dependent Variable: Profitabilitas

Nilai a adalah 9,010 dan nilai $b$ adalah $-0,065 c=0,339$ sehingga persamaan regresi linear berganda yang didapat adalah:

$$
Y=9,010-0,065 X_{1}+0,339 X_{2}
$$

- $\alpha=9,010$ artinya jika tingkat perputaran kas dan perputaran persediaan sama dengan nol ( 0 ), maka besarnya profitabilitas (ROA) 9,010 atau mengalami penambahan sebesar 9,010 .

- $\beta_{1}=-0,065$ artinya bahwa setiap peningkatan I kali perputaran kas maka profitabilitas (ROA) akan mengalami penurunan 6,5\% dengan asumsi variabel konstan.

- $\quad \beta 2=0,339$ artinya bahwa setiap peningkatan I kali perputaran persediaan maka profitabilitas (ROA) akan mengalami peningkatan 33,9\% dengan asumsi variabel konstan.

Dari persamaan regresi linear yang didapat dapat disimpulkan bahwa terdapat pengaruh yang negatif antara variabel $X_{1}$ (perputaran kas) terhadap variabel $Y$ (profitabilitas), artinya semakin tinggi tingkat perputaran kas maka profitabilitas semakin kecil, begitupun sebaliknya semakin kecil tingkat perputaran kas maka profitabilitas akan semakin besar. Sedangkan pengaruh variabel $X_{2}$ (perputaran persediaan) adalah positif terhadap variabel $Y$ (profitabilitas), artinya semakin tinggi tingkat perputaran persediaan maka profitabilitas akan semakin tinggi, begitupun sebaliknya semakin kecil tingkat perputaran persediaan maka semakin kecil pula profitabilitasnya.

Tingkat pengaruh atau tinggi rendahnya pengaruh perputaran kas dan perputaran persediaan terhadap profitabilitas dapat diukur dengan menggunakan persamaan koefisien determinasi. Berdasarkan hasil pengolahan data yang telah 
dilakukan dengan menggunakan SPSS versi 20.0 maka hasilnya secara lengkap disajikan dalam Tabel 8.

\section{Tabel 8. Koefisien Determinasi}

\begin{tabular}{lrccc}
\hline Model & $\mathrm{R}$ & $\mathrm{R}$ Square & $\begin{array}{c}\text { Adjusted } \mathrm{R} \\
\text { Square }\end{array}$ & $\begin{array}{c}\text { Std. Error of the } \\
\text { Estimate }\end{array}$ \\
\hline $\mathrm{I}$ & $.295^{\mathrm{a}}$ & .087 & .024 & 4.20439 \\
\hline
\end{tabular}

a. Predictors: (Constant), Perputaran Persediaan, Perputaran Kas

Berdasarkan pengolahan empiris, diperoleh angka $R^{2}$ ( $R$ Square) sebesar 0,087 atau $8,7 \%$. Hal ini menunjukkan bahwa persentase sumbangan pengaruh variabel independen (perputaran kas dan perputaran persediaan ) terhadap variabel dependen ( profitabilitas ) sebesar $8,7 \%$ atau variasi variabel independen yang digunakan hanya mampu menjelaskan sebesar $8,7 \%$ variabel dependen, sedangkan sisanya sebesar $91,3 \%$ dipengaruhi atau dijelaskan oleh variabel lain yang tidak dimasukkan dalam penelitian ini.

Uji ini dilakukan untuk menguji koefisien secara keseluruhan dan untuk mengetahui keberartian hubungan antara variabel independen secara bersama-sama dengan variabel dependen. Pengujian hipotesis akan menggunakan tingkat signifikan sebesar $5 \%=0,05$. Hasil penelitian dengan menggunakan program SPSS versi 20.0 dapat diperoleh output $f$ value pada Tabel 9.

\section{Tabel 9. Hasil Regresi Uji F}

\begin{tabular}{lllclll}
\hline Model & $\begin{array}{l}\text { Sum } \\
\text { Squares }\end{array}$ & of df & $\begin{array}{l}\text { Mean } \\
\text { Square }\end{array}$ & F & Sig. \\
\hline & Regression & 48.973 & 2 & 24.486 & 1.385 & $.266^{\mathrm{b}}$ \\
I & Residual & 512.630 & 29 & 17.677 & & \\
& Total & 561.603 & 31 & & & \\
\hline
\end{tabular}

a. Dependent Variable: $y$

b. Predictors: (Constant), $x 2, x \mathrm{I}$

Secara bersama-sama variabel independen tidak memiliki pengaruh yang signifikan terhadap variabel dependen. $\mathrm{Hal}$ ini dapat dibuktikan dari tingkat profitabilitas (ROA) sig. 0,266 menunjukkan 0,266 >0,05, maka $\mathrm{H}_{0}$ diterima, artinya tidak terdapat pengaruh yang signifikan dari perputaran kas $(X I)$ dan perputaran persedian $(X 2)$ secara simultan terhadap profitabilitas (Y).

Uji hipotesis parsial dapat diperoleh informasi sebagai berikut: (I) Perputaran kas mempunyai tingkat signifikansi 0,394 menunjukan 0,394 >0,05 yang artinya tidak ada pengaruh yang signifikan antara perputaran kas dengan profitabilitas (ROA). (2) Perputaran persediaan mempunyai tingkat signifikansi 0,110 menunjukan $0,110>0,05$ 
yang artinya tidak ada pengaruh yang signifikan antara perputaran persediaan dengan profitabilitas (ROA).

\section{Pembahasan}

Hasil penelitian diketahui bahwa secara simultan perputaran kas dan perputaran persediaan tidak memiliki pengaruh signifikan terhadap profitabilitas, Hal ini dapat ditunjukan dari nilai sig. 0,266 > 0,05 dan nilai $R$ Square 0,087 yang dapat diartikan bahwa variabel perputaran kas dan perputaran persediaan memberikan pengaruh sebesar 8,7 \% terhadap variabel profitabilitas sedangkan sisanya sebesar 91,3\% dipengaruhi oleh faktor lain yang tidak diteliti oleh peneliti. Hasil analisis menunjukkan variabel perputaran kas dan perputaran persediaan tidak berpengaruh terhadap profitabilitas pada perusahaan otomotif dan komponennya yang terdaftar di Bursa Efek Indonesia (BEI) periode tahun 2010 sampai dengan 2013.

Penelitian yang konsisten dengan hasil penelitian ini adalah: Rosmawati (2013) dengan judul penelitian pengaruh perputaran modal kerja terhadap profitabilitas pada perusahaan manufaktur di bursa efek Indonesia yang menunjukan perputaran kas dan perputaran persediaan tidak berpengaruh terhadap. Kemudian penelitian yang dilakukan oleh Feryal (2012) dengan judul penelitian Pengaruh Periode Perputaran Kas, Periode Perputaran Piutang, Periode Perputaran persediaan, dan Periode Perputaran Hutang Usaha Terhadap Profitabilitas (Studi Pada Perusahaan yang Listing di BEI Periode Tahun 2010 - 2012 yang hasil penelitiannya perputaran kas dan perputaran persediaaan tidak berpengaruh terhadap profitabilitas.

Penelitian yang inkonsisten dengan penelitian ini adalah: Ni Kadek (2013) yang berjudul Pengaruh Perputaran Kas, Perputaran Piutang, dan Perputaran Persediaan Terhadap Profitabilitas Perusahaan yang menunjukan hasil perputaran kas dan perputaran persediaan berpengaruh positif terhadap profitabilitas. Perbedaan ini dikarenakan banyaknya faktor yang mempengaruhi profitabilitas bukan hanya perputaran kas dan perputaran persediaan saja, aktiva lancar lainnya, hutang lancar, aktiva tetap juga memiliki peranan dalam menentukan besarnya tingkat profitabilitas. Kemampuan menghasilkan laba dapat dilihat dari hubungan antara pendapatan dan biaya yang dihasilkan dari penggunaan aktiva perusahaan baik aktiva tetap maupun aktiva 
lancar (Ridwan 2007) sedangkan pada penelitian ini hanya menggunakan aktiva lancar itupun hanya kas dan persediaan.

Perputaran persediaan tidak berpengaruh signifikan terhadap profitabilitas hal ini sejalan dengan teori yang diungkapkan oleh Kieso et al (2007) dimana peningkatan persediaan menjadikan indikator akan terjadinya penurunan laba. Disamping itu juga ketika perusahaan menghadapi penjualan yang lambat sementara persediaan terus bertambah akan menambah biaya penyimpanan, resiko kerusakan tinggi dan juga adanya penurunan harga sehingga pengurangi pendapatan penjualan dan laba menjadi rendah.

Hasil penelitian ini memiliki implikasi yang dapat memberikan gambaran mengenai rujukan-rujukan yang digunakan dalam penelitian ini. Gambaran ini dapat ditunjukan dari rujukan penelitian terdahulu dengan temuan penelitian yang sedang diteliti. Implikasi teoritis dikembangkan untuk memperkuat dukungan atas beberapa peneliti terdahulu yang menjelaskan tentang pengaruh perputaran kas dan perputaran persediaan terhadap profitabilitas. Konsep-konsep tentang teoritis dan dukungan empiris mengenai hubungan antar variabel yang mempengaruhi profitabilitas tidak tercermin pada hasil penelitian yang menunjukan bahwa perputaran kas dan perputaran persediaan tidak berpengaruh signifikan terhadap profitabilitas. Pengaruh terjadinya profitabilitas mungkin disebabkan faktor lain yang tidak dimasukan ke dalam variabel penelitian seperti perputaran piutang, aktiva lancar lainnya, aktiva tetap dan lainlain.

\section{SIMPULAN}

Berdasarkan hasil penelitian dan hipotesis yang telah dilakukan dan melalui beberapa tahap tentang pengaruh perputaran kas dan perputaran persediaan terhadap profitabilitas pada perusahaan otomotif dan komponennya yang terdaftar di Bursa Efek Indonesia (BEI) periode 2010-2013, maka peneliti dapat menarik kesimpulan sebagai berikut: (I) Perputaran Kas yang terjadi di perusahaan Otomotif dan Komponennya periode Tahun 2010 - 2013 rata rata mempunyai perputaran kas sebanyak 16 kali putaran dan termasuk dalam kriteria cukup. (2) Perputaran Persediaan yang terjadi di perusahaan Otomotif dan Komponennya periode Tahun 2010 - 2013 rata rata mempunyai perputaran Persediaan sebanyak 6 kali putaran dan termasuk dalam kriteria cukup. (3) Profitabilitas yang terjadi di perusahaan Otomotif dan Komponennya 
periode Tahun 2010 - 2013 rata rata mempunyai Profitabilitas sebesar 10,12\% dan termasuk ke dalam kriteria cukup. (4) Hasil pengujian korelasi perputaran kas menunjukan perputaran kas sangat rendah dan mempunyai arah negatif, Sedangkan perputaran persediaan menunjukan korelasi yang rendah. Hasil pengujian perputaran kas dan perputaran persediaan terhadap profitabilitas menyatakan bahwa perputaran kas dan perputaran persediaan secara simultan tidak berpengaruh terhadap profitabilitas pada perusahaan otomotif dan komponennya yang terdaftar di Bursa Efek Indonesia (BEI) periode 20I0-20I3, Begitu juga secara parsial masing - masing variabel tidak berpengaruh terhadap profitabilitas. Dari hasil uji koefisien determinasi menunjukan hanya 8,7 \% pengaruh perputaran kas dan perputaran persediaan terhadap profitabilitas sedangkan 91,3\% dipengaruhi oleh faktor faktor lain yang tidak dimasukan dalam penelitian ini.

\section{PUSTAKA ACUAN}

Agizha, Ferlay. 2013. Pengaruh Periode Perputaran Kas, Periode Perputaran Piutang,

Periode Perputaran Persediaan, dan Periode Perputaran Hutang Usaha Terhadap Profitabilitas Pada Perusahaan Manufaktur di BEl.

Albertus dan Amelia. 20I I. Pengaruh Perputaran Kas dan Perputaran Piutang Terhadap Rentabilitas Ekonomi Pada KPRI di Lingkungan BKN. Tesis Tidak Dipublikasikan. Jakarta: Institut Bisnis Nusantara.

Baridwan, Zaki. 2004. Intermediate Accounting. Edisi Kedelapan. Yogyakarta: BPFE.

Harahap, Sofyan, Syafri. 20I0. Analisis Kritis Atas Laporan Keuangan. Jakarta: Bumi Aksara.

Kasmir. 2008. Analisis Laporan Keuangan. Jakarta: PT Raja Grafindo Persada.

Kasmir. 20I I. Dasar-dasar Perbankan. Jakarta: Rajawali Pers.

Kieso, Weygandt dan Warfield. 2007. Akuntansi Intermediate. Edisi Keduabelas Jakarta: Erlangga.

Lukman. 2009. Manajemen Keuangan Perusahaan, Konsep, Aplikasi dalam Perencanaan Pengawasan dan Pengambilan Keputusan. Jakarta: Rajawali Press.

Ni Kadek dan I Putu. 2013. Pengaruh Perputaran Kas, Perputaran Persediaan, dan Perputaran Piutang Terhadap Profitabilitas Pada Perusahaan Food and Beverage Di BEI. Jurnal Ilmiah Mahasiswa Universitas Udayana. 
Nina dan Ni Ketut. 20 10. Pengaruh Perputaran Kas, Perputaran Piutang dan Perputaran Persediaan Terhadap Profitabilitas. Jurnal Ilmiah Mahasiswa Universitas Udayana.

Putu Intan dan Gede Merta. 20II. Pengaruh Modal Kerja Terhadap Profitabilitas Pada Perusahaan Food and Beverage Di BEl. Jurnal Ilmiah Mahasiswa Universitas Udayana.

Riyanto, Bambang. 200I. Dasar-Dasar Pembelanjaan Perusahaan. Edisi Keempat. Yogyakarta: BPFE Yogyakarta.

Rosmawati. 2013. Pengaruh Perputaran Modal Kerja Terhadap Profitabilitas Perusahaan Manufaktur di BEl. Skripsi Tidak Dipublikasikan. Depok: Universitas Gunadarma.

Sartono, Agus. 201I. Manajemen Keuangan Teori dan Aplikasi. Yogyakarta: BPFE.

Smith, Jay, M. 1996. Akuntansi Intermediate. Cetakan Sembilan. Jakarta: Erlangga.

Stanislaus S, Uyanto. 2009. Pedoman Analisis Data Dengan SPSS. Yogyakarta: Graha IImu.

Stice, James D Stice dan Skousen (2004), Intermediate Accounting I5th Edition. Jakarta: Salemba Empat.

Sugiyono. 2013. Metode Penelitian Kuantitatif Kualitatif dan $R$ \& $D$. Bandung: Alfabeta.

Sundjaja, Ridwan. 2007. Manajemen Keuangan I. Bandung: Unpar Press.

Warren, Carl S. Reeve, James M. and Fess. 2005. Pengantar Akuntansi. Jakarta: Salemba Empat. 